\title{
Promotion Opportunity Relationship With Job Satisfaction of Nurses Implementing in the Patient's Room Hospital Pariaman
}

\author{
Hilma Yessi \\ Associate's Degree of Nursing, Universitas Negeri Padang, Padang, Indonesia \\ *Corresponding author. Email: aulia.asman@gmail.com
}

\begin{abstract}
Job satisfaction is a positive attitude toward work in a person. The research objective was to determine the promotion opportunity sale with job satisfaction of nurses in the inpatient unit Pariaman Public Hospital. Type descriptive correlational, cross-sectional design. The population of the entire inpatient nurses, 96 nurses sample, proportional sampling technique. Collecting data using questionnaires. The data analysis of univariate, bivariate, multivariate. Results of research nurses aged 20-35 years (59.4\%), female (87.5\%), Diploma III (66.7\%), length of $>5$ years $(62.5 \%)$, married $(74,0 \%)$, high promotional opportunities $(53.1 \%)$, job satisfaction level was $(51.0 \%)$. There is no relationship between the characteristics of nurses and promotional opportunities with job satisfaction, the hospital is expected to empower nurses in accordance with the education and training they have.
\end{abstract}

Keywords: Job Satisfaction, Opportunity Promotion

\section{INTRODUCTION}

Job satisfaction is an affective or emotional responses to the various facets of a person's job (Kreitner, 2014). Meanwhile, according Juliansyah (2013) job satisfaction is the individual, the more aspects - aspects of the job in accordance with the desires of the individual, the higher the perceived level of satisfaction and vice versa. According Wibowo (2013) factors - factors related to job satisfaction: leadership, the work itself, pay, promotion opportunities, supervision, coworkers, feedback.

World data on job satisfaction over half of nurses in Germany $61 \%$ are satisfied with opportunities for advancement, while nurses in the United States more than half $(57 \%)$ and Canada more than half $(69 \%)$ are satisfied with their salaries (Lorber \& Savic, 2012). Schermerhorn, Jr, John R, James. Hunt, Richard N. Osborn, and Mary Uhl-Bien, (2011) cited in Wibowo (2013) suggested that the United States $65 \%$ of workers get job satisfaction. Research Curtis (2007) showed that the professional status, interaction and autonomy provide the largest contribution to job satisfaction of nurses.

\section{RESEARCH METHODS}

This research is a quantitative correlation descriptive and cross sectional study to find the relationship variables. The study is the correlation description of research that aims to explain the relationship between the variables in one situation or a group of subjects (Notoadmojo, 2006) and cross sectional meaningful measurement of the dependent variable and independent variables executed one at a time (Sastroasmoro \& Ismael, 2010). The independent variable in this study is Promotion opportunities and the dependent variable is job satisfaction of nurses. In this research to find the relationship of independent variables and the dependent variable in Pariaman Public Hospital in 2016. This study used a questionnaire that data source. the sample is diruang inpatient nurses Pariaman Public Hospital. The sampling method in this research is proportional random sampling. Sample this research were 96 nurses from all nurses, amounting to 126 people. Pariaman Public Hospital where the research study period from January 2016 to January 2017, the ethics of research with informed consent (approval), anonymous, confidential, principled keadilandan profitable and beneficial, and respecting human rights. A questionnaire data gathering tool that individual characteristics questionnaire and questionnaire B is job satisfaction questionnaire with 20 questions, promotional opportunities with 9 questions the validity of the test carried out in hospitals Solok. Reliability testing is done by one shot or measurements once sajalalu membandingkn hsilnya with other statements. 


\section{RESEARCH RESULT}

Characterizing the nurses showed that more than half $(59.4 \%)$ of nurses aged 20-35 years, most of the nurses were female $(87.5 \%)$, more than half of nurses educated D3 (66.7\%), more than half life of $>5$ years (62.5), and over half of the caregivers were married (74\%) and more than half of the nurse's perception of high promotion opportunities $(53.1 \%)$ can also note that more than half of the caregivers are satisfied at work 49 ( $51 \%)$.

\section{DISCUSSION}

It can be seen that a female nurse is able to survive in any condition compared with male nurses men. Female nurses better able to deal lingkngan nurse jobs compared to men - men. The gender difference does not impede a nurse to perform activities despite the heavy work done. Gender does not affect the role and functions as the nurse. Male or female nurses working in accordance with their job descriptions - each nurse has been determined.

Characteristics of nursing education Pariaman Hospital inpatient diruang is Diploma III. No educated $\mathrm{S} 2$. Besides, the number of nurses who continue their education is still lacking $\mathrm{S} 1$ nurses nurse cause is difficult to adjust the timing of lectures with working hours as well as the hospital does not provide the cost of education for employees so that the cost borne by the nurses themselves. The education level of less affect the position of one's position in the hospital because of the employment status and working time better define one's position.

Future work undertaken by nurses diruang Pariaman Hospital inpatient this is the life of over 5 years, which have seniority, the nurse will be able to make adjustments to the work environment so as to achieve daam job satisfaction. Another cause is also put forward the policy of the agency or company on life insurance in the old days.

It can be seen that the wedding would make a more responsible than the nurses who are not married, it proved their sense of who is responsible is very high in meakukan duties and functions of each - each nurse promotion opportunitieswould result in a different effect on job satisfaction. Promotional opportunities given by superiors to subordinates will cultivate a sense of higher responsibility in which recognition is very influential on the performance of a nurse. Promotional opportunities nurse will also provide an opportunity to further develop a career nurse, more responsibility, and social status meningekat. If the increased social status also increased nurse satisfaction and patient satisfaction also increased even no more inequality which is already equal to the task with the same understanding of each individual function.

\section{CONCLUSION}

Characteristics of nurses diruang Pariaman Hospital inpatient nurses mostly early adult age, mostly female, mostly educated Diploma, most of the work period of more than five years, the vast majority are married

Job satisfaction of nurses diruang Pariaman Hospital inpatient more than most nurses are satisfied at work, not much different from most of dissatisfied at work There is no relationship between age, gender, education, marital status, tenure, promotion and job satisfaction of nurses in the inpatient unit Pariaman Public Hospital

\section{SUGGESTION}

Each nurse in hospitals Pariaman can contribute to increasing the performance by means of an active role in a variety of nursing scientific activities such as seminars, training, workshops held both inside and outside the organization.

\section{REFERENCES}

[1] Aditama,T.Y. (2010). Manajemen Administrasi Rumah Sakit, Jakarta : Penerbit Universitas Indonesia Press

[2] American Nurses Credentialing Center (ANCC, 2008), Aplication Manual Maqnet Recognition Program: Georgia Findings. Nursing Outlook,50:187-194

[3] Alamsyah.(2014).Manajemen Pelayanan Kesehatan.Jakarta :EGC

[4] Arikunto. (2013). Prosedur Penelitian :Suatu Pendekatan Praktik.Jakarta :Rineka Cipta

[5] Argapati, Noor \& Sidin (2013). Gambaran Kepuasan Kerja Perawat Rawat Inap

[6] Rumah Sakit Stella Maris Makasar. FKM Makasar.

[7] Arief Subyantoro. (2009). Pengaruh Karakteristik Individu, Karakteristik Pekerjaan Karakteristik Organisasi Terhadap Kepuasan Kerja dan motivasi Kerja (Studi pada Pengurus KUD di Kabupaten Sleman). Jurnal Manajemen dan Kewirausahaan, Vol. 11 tahun 2009

[8] Andi Setiawan.( 2012). Pengaruh Karakteristik Individu dan Faktor-Faktor 
[9] Pekerjaan Terhadap Motivasi (Studi Pada Karyawan CV. Bintang Timur Semarang)

[10] Arikunto,(2013). Prosedur Penelitian.Suatu Pendekatan Praktik. Jakarta ; Rineka Cipta

[11]Badeni.(2013). Kepemimpinan dan Prilaku Organisasi.Bandung : Alfabeta

[12]Baumann.A.(2007). Positif Praktice Environment : quality workplaces = quality

[13] patient care, International Council of Nurses

[14] Bratt, M.M. Broome, M.Kelber, S, \&Lostocco, L. (2000). Influence of Stress and

[15]Nursing Leadership on Job Satisfaction of Pediatric Intensive Care Unit Nurses. American Jurnal Of Critical Care,9(5), 307-317.

[16]Chen,YM.(2008). Nurses Work Environment And Satisfaction, http://proquest.umi.com/pqdweb? Diakses tgl 6 Februari 2016

[17] Cortese (2007) Job satisfaction of Italian Nurses: an exploratory study. Jurnal of Nursing Manajemen. Vol 15 Issue 3.

[18] Curtis. (2007). Job Satisfaction: a survey of Nurses in The Republikc Ireland. Jurnal of Nursing Management.Vol 54.Issue 1,

[19] Chimanikire, p. (2007). Factor that affecting job satisfaction among academic

[20] profesional in tertiary institution in Zimbabwe

[21] College Of Registered Nurse Of British Columbia (CRNBC), Guidelines For A

[22] Quality Practice Environment For Nurses In Britsh

Columbia.http://wwwcrnbc.ca./downloads/409/ pdf diakses tgl 10 Februari 2016

[23] Depkes. (2006). Pedoman Penyelenggaraan dan prosedur Rekam Medis Rumah.

[24] Sakit di Indonesia. Jakarta: Departemen Kesehatan RI

[25] Depkes RI. (2008). Rencana Strategi Nasional Making Pregnancy Saper (Mps) di

[26] Indonesia 2001-2010. Sekretariat Jendral

[27] Depkes. (2009). Sistem Kesehatan Nasional RI $\therefore$ Jakarta

[28]Delfina, R. (2015). Analisa Faktor -faktor Yang berhubungan Dengan Kepuasan
[29] Kerja Perawat Pelaksana Di Ruang Rawat Inap RSUD Dr. M Yunus Bengkulu.Tesis tidak dipublikasikan

[30]Huber, D. (2006). Leader and Nursing Care Manajement. Philadelpia : Suner

[31] Hariyati. (2014). Perencanaan. Pengembangan dan Utilisasi Tenaga Keperawatan. Jakarta ; Raja Grafindo Persada

[32] Hasibuan,h.M.S.P.(2009). Manajemen Sumber Daya Manusia.PT Bumi Aksara : Jakarta

[33] Hayat, Nahrul. (2015). Hubungan Karakteristik staf dan Tim Kerja dengan Kepuasan Kerja Perawat di Rumah Sakit Tipe B Kota Batam. Tesis FkepUnand. Tesis tidak dipublikasikan

[34] Kuntoro, Agus. (2010). Buku Ajar Manajemen keperwatan. Yogyakarta : Nuha Medika 